\title{
S)
}

ISSN 2278 - 0211 (Online)

\section{An Appraisal of Energy Efficient Buildings towards Improving Living Standards in Nigeria}

\author{
Weli-Wonodi, Ikekah \\ Student, Department of Architecture, Rivers State University, \\ Nkpolu Oroworuko, Port Harcourt, Nigeria
}

\begin{abstract}
:
Buildings in Nigeria today, rely solely on the National grid for power supply, expect a few who run on alternative power supply of generators and solar powered inverters. The increasing population in Nigeria has left power supply from the national grid, in capable to distribute to all buildings in the country. To handle this incapability, a method of rationing power supply is been adopted, where power is distributed at different time intervals to different regions of the country. In the absence of power supply, private generators are used which poses adverse effects of; noise pollution, health hazards, environmental pollution also high expense on maintenance and fuel purchase is involved. Institutions like the European Union \& the German Federal Ministry for Economic Cooperation and Development (BMZ) have seen this to be a problem and are proffering solutions to eliminating or reducing this economic setback. In proffering solution, this paper has presented the concept in energy efficient buildings as an approach to reducing the reliance of buildings in Nigeria on the national grid but exploring other eco-friendly design and construction approaches in achieving energy for the built environment. In highlighting this approach, a purposeful selection of existing energy efficient buildings around the world was studied, identifying the features and approaches to energy efficiency they possess in line with the Leadership in Energy and Environmental Design (LEED)standards. This approach presents to the Nigeria Architects, her allied profession and the government, promising solution to bettering living standard in the country.
\end{abstract}

Keywords: Alternative energy, power supply, Nigeria, energy saving in buildings, LEED

\section{Introduction}

It is estimated that around $40 \%$ of the annual energy consumed in the world is used in the buildings today. For lighting, cooking, heating and air-conditioning. These functions not only consume energy but release greenhouse gases. (Harputlugil, 2017).The Building Energy Efficiency Guideline for Nigeria published a consumption rate of only residential buildings in Nigeria at more than $50 \%$ of the total energy consumed by the country as at the year, 2014. Presently in 2019, this percentage in consumption have taken a shift up the graph as there is an increase in population as well increase in the erection of more residential buildings. In Nigeria, living standards deteriorate daily as power supply has not been managed properly. In other to provide alternative power supply to charter for human activities, generators are used. Long exposure of carbon emissions is detrimental to the ozone layer, the environment and to the users (Oseni, 2016). There are recorded deaths as a result of fume inhalation from generators which cause respiratory infections. But with the execution of energy efficient building approaches, changes will emanate in Nigeria living standard. Energy Efficiency in buildings utilizes less energy to maintain or improve indoor comfort for the users of the building. This energy utilized is less harmful to the environment and are cost effective (Building Energy Efficiency Guideline for Nigeria, 2016). The Chartered Institute of Building Service Engineers (CIBSE, 2012) describe energy efficient buildings to be one that provides the required internal environment and services with minimum energy use in a cost effective and environmentally sensitive manner. Module 18(sustainable energy regulation and policymaking for Africa) defines energy efficiency of a building as the degree to which the energy consumption per square metre of floor area of the building measures up to established energy consumption benchmarks for a particular building type under defined climatic conditions.

The guideline of the energy efficient buildings for Nigeria has advised all professionals and stakeholders in the building industry to plan, design and construct buildings that are energy efficient complainant to benefit the environment and generations to come.

\subsection{LEEDS' Approach to Energy Efficiency in Buildings}

Leadership in Energy and Environmental Design (LEED)was established in the US in 1998as a rating system by the U.S. Green Building Council to support national standard to the enhancement of the living standard of users of facilities, based on the assessment of the environment and economic gain of the facility. LEED rating system was developed in order 
to elevate an entire approach to construction and to encourage green certification of buildings.(Barshilia,2014),(Fedkin, 2018)

\subsubsection{Categories of Assessment to Which Buildings Are Confirmed to Be Energy Efficient Are:}

\subsubsection{Sustainable Sites}

For sites to be sustainable, the following should be considered;

- Adhering to town planning regulations.

- Deliberate control of erosion.

- Managing storm water around the site.

- Limiting light pollution.

- Reducing heat island effect.

- Having access to public transport.

- Provision for alternative transportation.

- Protecting and restoring open spaces.

- Accessing social amenities.

- Encouraging pedestrian connectivity

\subsubsection{Water Efficiency}

- Using rain water or recycled water for irrigation.

- Eliminating the use of drinking water for landscape irrigation.

- Introducing waste water technologies.

- Making efficient use of water within building to reduce burden on source.

\subsubsection{Energy and Atmosphere}

- Ensuring Proper operation of building elements and systems.

- Establishing minimal energy efficiency for buildings.

- Reducing ozone depletion.

- Encouraging alternative energy supply void of fossil fuel.

- Encouraging metering of energy consumption to validate end use.

\subsubsection{Materials and Resources}

- Providing a measure for control and hauling of waste generated by occupants.

- Ensuring avoiding waste in building reuse by maintaining $75 \%$ walls, floors and roof.

- Redirecting Debris from demolition and land clearing for reuse.

- Putting back to use building materials and products in building reuse to discourage demand for virgin materials.

- Boasting the Economic of the region should be encouraged by patronising locally made products.

- Encouraging Forest management for wood production and use.

\subsubsection{Indoor Environmental Quality}

- Creating indoor air quality performance for the comfort of occupants.

- Protecting building occupants from Environmental Tobacco Smoke (ETS).

- Monitoring the Capacity for indoor air quality for occupants comfort.

- Ensuring effective supply and control of fresh air for occupants' comfort both during and after construction or renovation.

- Using adhesives, sealants, coatings and paints that are odourless and not harmful to occupants.

- Ensuring the connection of occupants with the indoor and outdoor spaces.

- Ensuring high ventilation, thermal and lighting system control.

\subsubsection{Innovation in Design}

Professionals should integrate in their design process, all that it takes to make buildings energy efficient, by taking advantage of the local climate to make buildings environmental friendly.

\subsection{Strategies to Energy Efficient Buildings}

Generating energy efficient building kicks off with the a well thought design approach, considering the local climate conditions of the site, orientation, building form, choice of goal oriented and cost effective building materials and building envelope systems which reduces heat gains. Exhausting these passive strategies then the active systems could be carefully chosen with consideration to high efficiency (e.g. energy saving lighting systems) to allow for reduction of cooling loads suitable to the climate.

\subsubsection{Passive Design Approach}

Passive design functions by taking advantage of natural energy to retain thermal comfort. It utilises correct building orientation, building materials and landscaping. The buildings should be properly positioned, taking advantage of 
wind path and sunlight and the makeup of the building envelope should be able to minimize heat gain. Shading also should be provided to minimize solar radiation (Agboola 2011).Passive design elevates the concept of climate friendly strategies to providing buildings with comfortable indoor air quality void of less or no mechanically stimulated environmental pollutants. (Hasim A., Mona H., Kheira A., Akash D, 2016).

\subsubsection{Orientation}

Orientation describes the way a building is positioned on site, making good use of the elements of climatic such as sun and wind path (McGee,2013).Well-designed buildings should be oriented, and the spaces arranged in such a way, that the majority of rooms face towards the equator. In this way, the eastern and western sides are exposed to the low-angle summer sun in the morning and afternoon. The longer north/south sides of the building benefits from the low angle sun in winter. The roof overhang or shading on the equator side should allow the Sun to shine into the building when its warmth is required in winter, and provide adequate protection from high-angle Sun in summer (Aksoy and Inalli 2006).

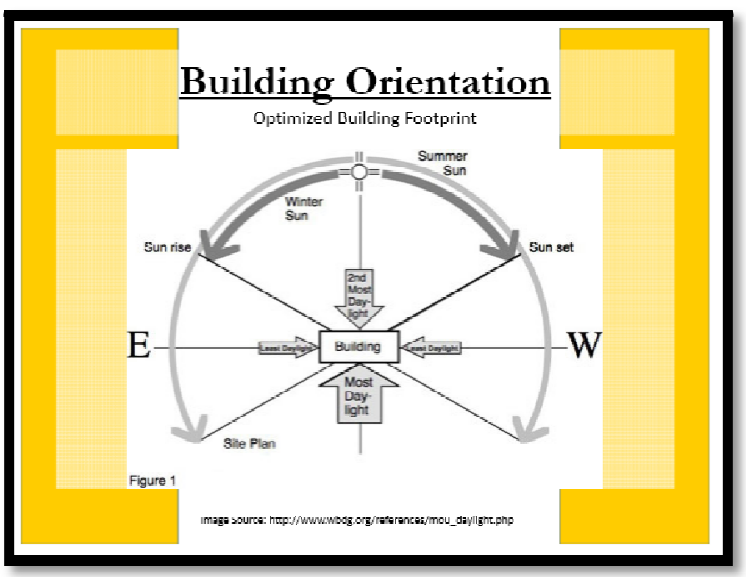

Figure 1: Illustration of Building Orientation

Source: http://www.wbdg.org/reference/mou_daylight.php (2019)

\subsubsection{Fenestrations}

These are openings in buildings, for the purpose of bringing in natural light, exchange of air and control access in and out of a building. Examples are windows, doors and perforated walls. Windows take full responsibility to excessive heat gain and loss in buildings. In as much as it possesses more merits to its demerits and its types should be under studied with relation to its impact and effect to the building. To manage the effect of heat in and outside a building through windows, you need to determine how big or small, how high or low and how sealed or porous they should be, having in mind evaporation and draughts. (McGee, 2013).

\subsubsection{General Shading}

Passive design has to do with regulating how the building absorbs heat additional keeping heat away from particular parts of the building when necessary. Carefully designed canopies, frameworks and eaves can support shading. An advantageous and most natural way to provide shade where sunshine is not needed is to plant some ever green trees that'll shed their leaves and give way to the sun in winter. Outdoor shading elements are the most effective protectors against the sun by avoiding up to $90 \%$ of heat gain (Lechner, 2014), (McGee, 2013). Majority of shading devices possess either vertical fins, horizontal overhangs or both combined. The overhangs possess a lot of variations and are better choices to usage for the south façade especially in the tropics where solar heat gain is not needed. The eaves are to extend to at least $800 \mathrm{~mm}$ wide and placed above windows to make sure they properly protect windows and walls from direct solar radiation (Cairns Regional Council, 2014).

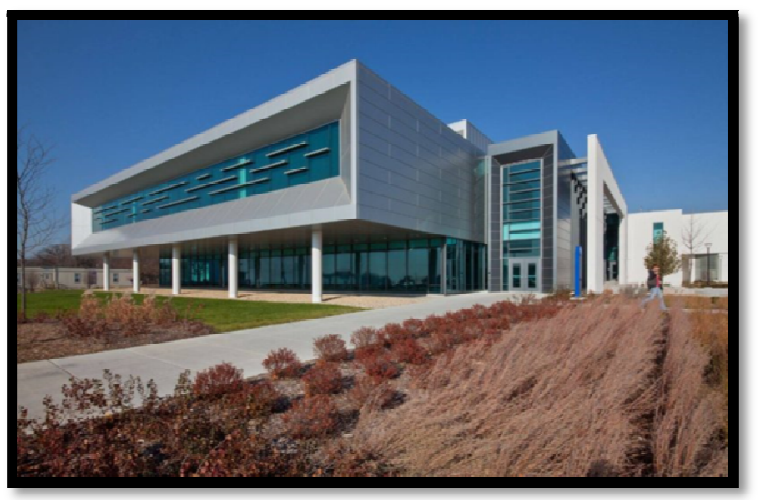

Figure 2: Illustrating General Building Shading Source: Marcy (2018) 


\subsubsection{Colour}

The application of the right colours on external surfaces of buildings affects the absorption, or reflective rate of solar radiations. Light colours on the external surfaces of buildings help to lower heat build-up (Gibberd, 2009), Givoni \& Hoffman claimed that, the small unventilated buildings walls painted with white-colour in Israel were approximately $3{ }^{\circ} \mathrm{C}$ cooler in summer than the same buildings painted with grey colour. (Hossein O., Abdul M., 2015)Research has proved that the amount of air-conditioning in many buildings will reduce by $20 \%$ just by increasing the solar reflectivity of the walls and roofs from a typical medium-dark value of $30 \%$ to a light-coloured value of $90 \%$. "Albedo" which is also known as solar reflectivity, is a number that shows what amount of the solar radiation is reflected from a surface. An albedo of 0 shows the absence of sunlight reflection while an albedo of 1 points out the reflection of sunlight. White colour has the highest amount of solar reflectivity with an albedo of about 0.9 ( $90 \%$ is reflected) if it is fresh, clean, and glossy (Lechner, 2014).

\subsubsection{The Building Envelope}

Building envelope is said to an enclosure of a built environment, which comprises of walls, doors, windows, roof, floor and skylights, and other openings for light and ventilation. Building envelope as the totality of (building) elements made up of components which separate the indoor environment of the building from the outdoor environment (Oral et al., 2004). The envelope protects the building's interior and occupants from the weather conditions and other external elements. Design features of an envelope strongly affect the visual and thermal comfort of the occupants, as well as energy consumption in the buildings. (Kumar; Raheja 2016).

\section{Methodology}

The idea of this research is to assess the value of energy efficient buildings as it enhances the living standard of Nigerians. A case study approach was carried out on four existing energy efficient buildings as rated by LEED, around the world. The primary aim is to look out for the features of energy efficiency in these buildings based on the environmental performance approach of LEED for energy efficient buildings. With the findings deduced from the case studies a conclusive layout is drawn out showing how much of LEED's features in energy efficiency in buildings have been adopted.

\subsection{Case Study One}

Findings made from the case study of the Pearl River Tower have shown its eligibility of being categorised as energy efficient building. The 71 storey office building in Guangzhou, China began its energy efficiency ambition on the aim of achieving a building which consumes nearly $60 \%$ less energy than a traditional building. The building design process began with making use of the local climate as a source to energy production. In so doing, the building was oriented to take optimal advantage of the wind and sun to generate energy to power the building. The building envelope was also used for energy efficiency by covering it with photovoltaic cells to tap solar radiation, transmit electricity and protect the interior space from solar radiation. Its aerodynamic form attracts and accelerates the wind to power its four huge turbines. Walls of the building allow a flood of light to converse electricity, a protective layer on the façade to capture excess heat from the sun, keeping the interior space cool in the absence of air-conditioning.

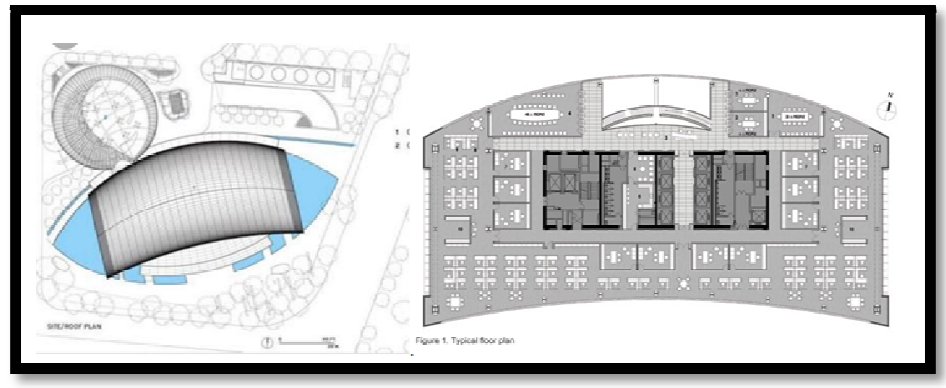

Figure 3: Site plan and Typical Floor Plan

Source: Council on Tall Buildings and Urban Habitat (2013)

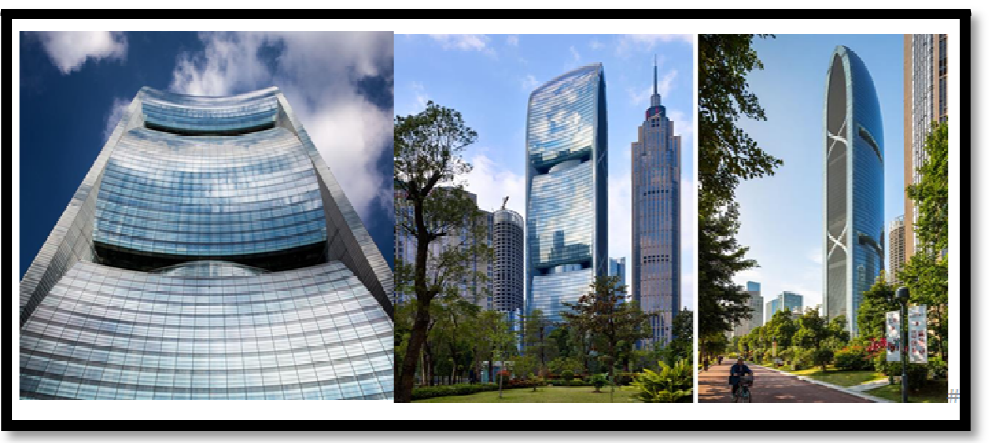

Figure 4: Showing Energy Efficiency Approach.

Source: Council on Tall Buildings and Urban Habitat (2013) 


\subsection{Case Study Two}

Findings made from the case study of the 8 house having won prizes of sustainability have shown its eligibility of being categorised as energy efficient building. The 11 storey, $61,000 \mathrm{~m} 2$ figure 8 shaped mixed building in Copenhagen, Denmark, began its energy efficiency from the conceptual stage in designing a building that conserves energy. The building uses planting of trees at entrances, roof top gardens and a green roof design to reduce urban heat effect. In optimising the local climate, its form, the figure 8 creates an uninterrupted natural day lighting and air flow performance to the building through the provision of courtyards. The building envelope is covered with glass panels to allow daylight and connect the interior space to the external.

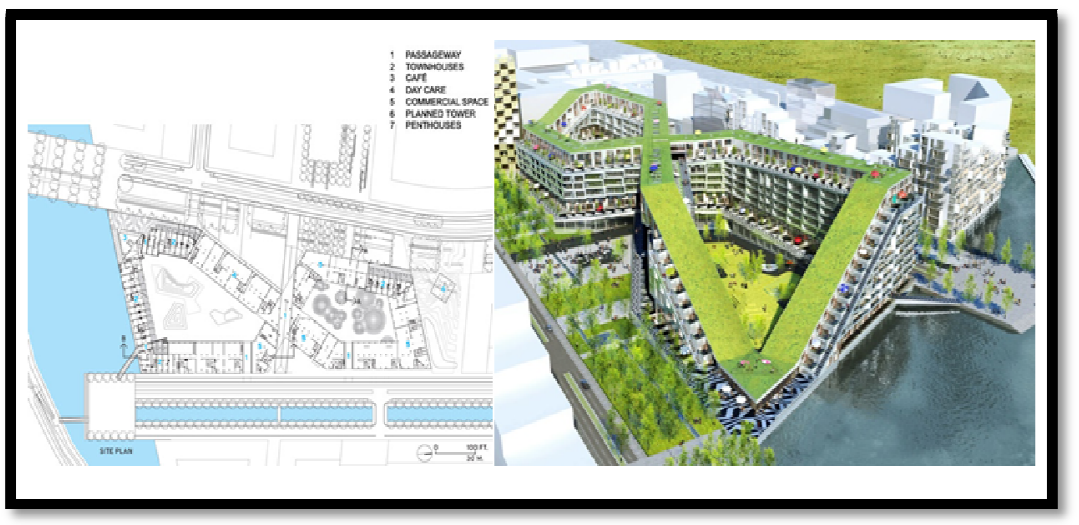

Figure 5: Site Plan and View Showing the Use of Green Roof System Source: (Minner, 2010)

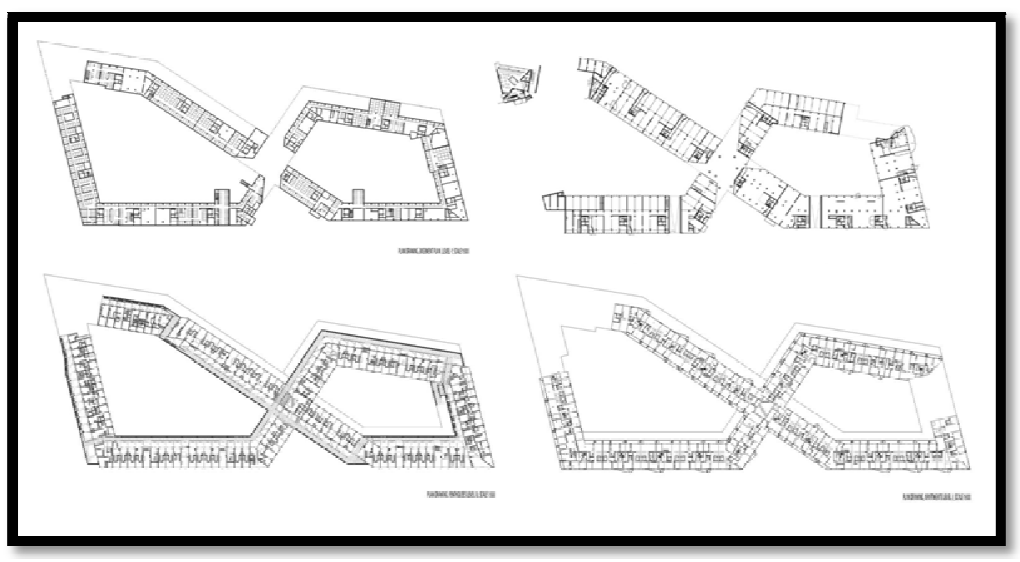

Figure 6: Floor Plans

Source: (Minner, 2010)

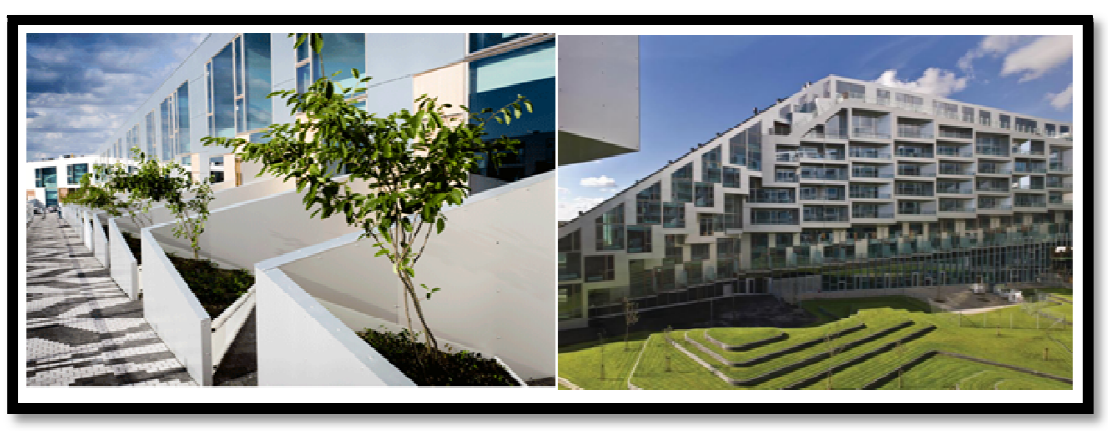

Figure 7: Tree Planting at Entrances and Fenestration as an Approach to Energy Efficiency.

Source: (Minner, 2010)

\subsection{Case Study Three}

Findings made from the case study on the Bullitt Centre have shown its eligibility of being categorised as energy efficient building. The 6 storey, 4645sqm urban office building in Seattle, America, dived into its energy efficiency quest after much research work on how technology and decisions in design could be used in building enclosure to achieve high energy efficient performance. Taking advantage of the micro climatic was the best move. Orientation gives optimum advantage from the sun to generate energy to power the building and windows positioned at different facade to optimize day lighting. The roofing sheets are entirely photo voltaic panels which tap solar energy worth $230,000 \mathrm{kwh}$ per year. With an average of 150days of rain per year, the Bullitt Centre harvest rain water and all waste water from the building, taking 
them through a filtration, treatment and polishing process. The materials used for the building construction are locally sourced materials.

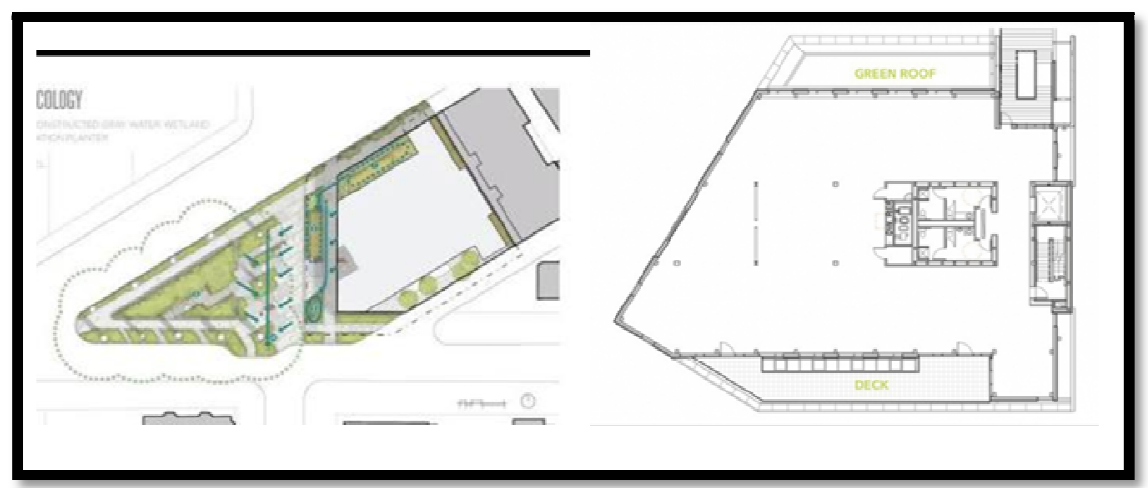

Figure 8: Site Plan and Floor Plan

Source: Whole Building Design Guide (2016)

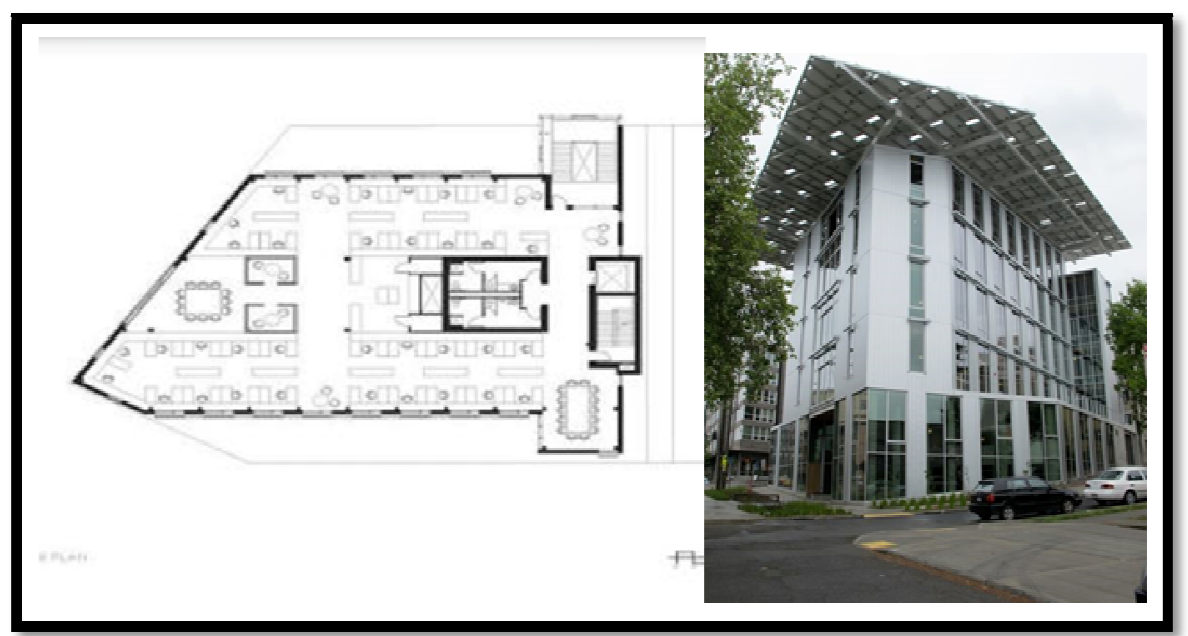

Figure 9: Floor Plan and 3d view

\subsection{Case Study Four}

Findings made from the case study on the Bullitt Centre have shown its eligibility of being categorised as energy efficient building. The H-E-B at Mueller, is a 83,600 sq. ft. retail store, fresh food market, a pharmacy, cafe and community meeting space. It is located in the Mueller neighbourhood, a mixed-use urban village in Austin, Texas, U.S.A. The building adopts some features of sustainable design innovations in energy generation and portable water use.

The Roof has mounted on it solar photovoltaic system of $169 \mathrm{~kW}$ covering 11,000 sq. $\mathrm{ft}$. which powers all the store's lighting, propane refrigeration system which are ozone friendly/cooling system to integrated day lighting, computer automated LED lighting resulting in an estimated $23 \%$ energy savings. The project is built with sourced sustainable materials which are low emitting, free of toxic chemicals harmful to human health, and preserving natural resources. Additionally, the site has good connectivity, bike parking area, and electric car charging spots supporting alternative transportation.

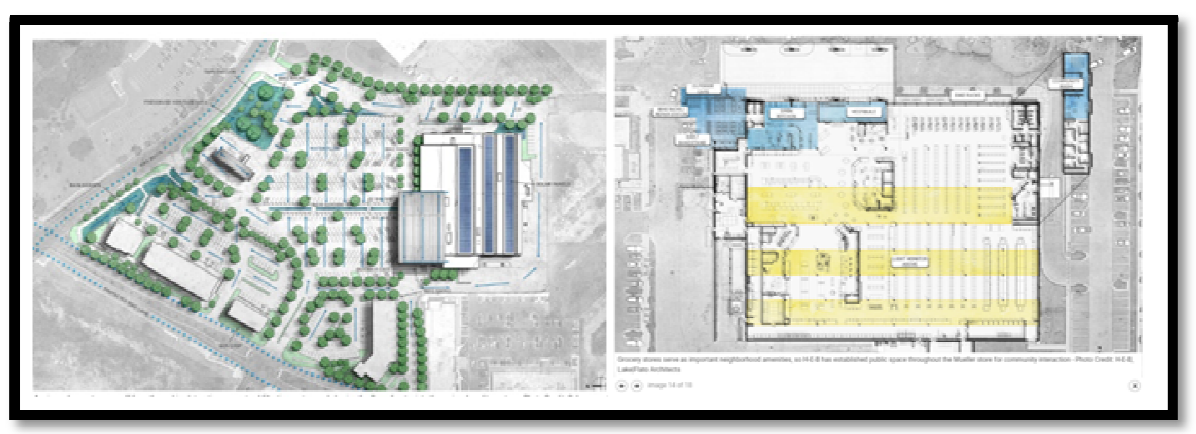

Figure 10: site Plan and Floor Plan Source: (Wood, 2019) 


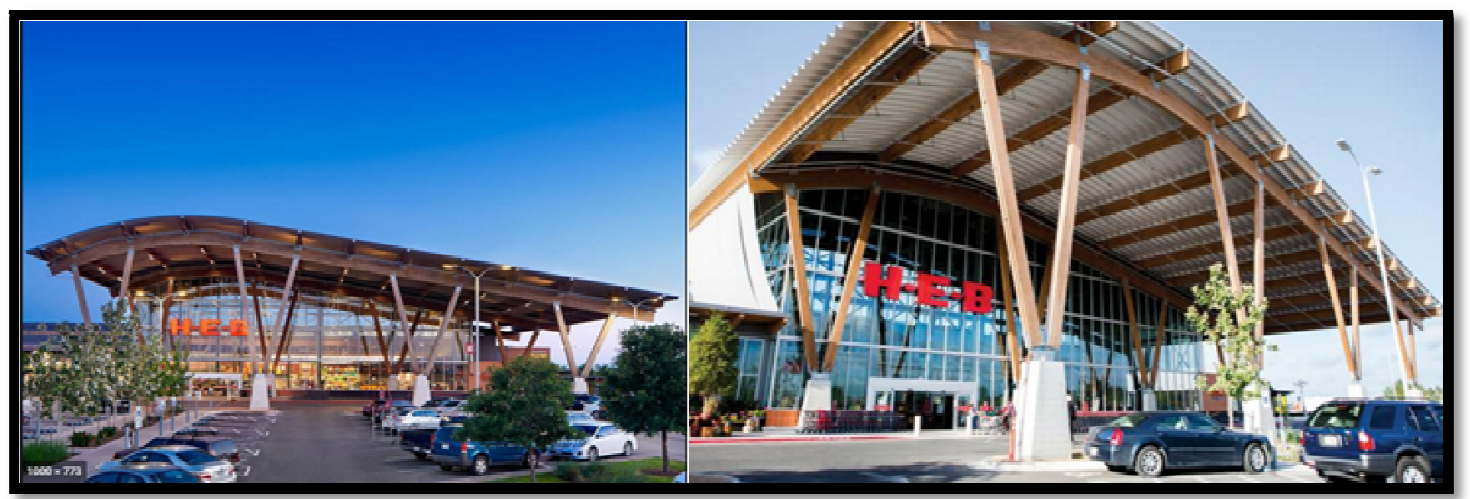

Figure 11: Showing Innovation as an Approach to Energy Efficiency in Buildings Source: (Wood, 2019)

\begin{tabular}{|c|l|l|l|l|l|l|}
\hline \multirow{2}{*}{ Case Studies } & \multicolumn{7}{|c|}{ Leed Features } \\
\cline { 2 - 7 } & & $\begin{array}{c}\text { Water } \\
\text { Efficiency. }\end{array}$ & $\begin{array}{c}\text { Energy And } \\
\text { Atmosphere. }\end{array}$ & $\begin{array}{c}\text { Material } \\
\text { Resources } \\
\cdot\end{array}$ & $\begin{array}{c}\text { Indoor } \\
\text { Environmental } \\
\text { Quality. }\end{array}$ & $\begin{array}{c}\text { Innovation } \\
\text { Design. }\end{array}$ \\
\hline $\begin{array}{c}\text { Case Study One } \\
\text { Pearl River Tower }\end{array}$ & $\checkmark$ & & $\checkmark$ & $\checkmark$ & $\checkmark$ & $\checkmark$ \\
\hline $\begin{array}{c}\text { Case Study Two } \\
\text { 8 House }\end{array}$ & & $\checkmark$ & $\checkmark$ & $\checkmark$ & $\checkmark$ & $\checkmark$ \\
\hline $\begin{array}{c}\text { Case Study Three } \\
\text { Bullitt Center }\end{array}$ & $\checkmark$ & & $\checkmark$ & $\checkmark$ & $\checkmark$ & $\checkmark$ \\
\hline $\begin{array}{c}\text { Case Study Four } \\
\text { H-E-B At Mueller }\end{array}$ & $\checkmark$ & $\checkmark$ & $\checkmark$ & $\checkmark$ & $\checkmark$ & $\checkmark$ \\
\hline
\end{tabular}

Table 1: Showing the Features of LEED Standard Adopted by the Different Case Studies.

\section{Conclusion and Recommendation}

This paper has succeeded to bringing to limelight, through the case studies done on the randomly selected buildings, the features for LEED's standard for energy efficient buildings. These features are what every developer should have as concepts guiding their designs.

Presently in our World, energy generation, usage and storage for buildings can be achieved effortlessly if only ideas are put to work. The solution to energy efficiency is only making maximum use of the micro climate in our environmental. Buildings types in Nigeria have an opportunity to run on efficient alternative power supply and less reliance on the National grid in so doing create an improved standard of living for the citizens of Nigeria.

\section{References}

i. Agboola OP (2011) Importance of climate to architectural designs in Nigeria. Environ Issues Agric Developing Countries 3(1) (pp. 15-28)

ii. Aksoy, U.T., \& Inalli, M. (2006). Impacts of Some Building Passive Design Parameters on Heating Demand for a Cold Region. Build Environ 14(12): (pp1742-1754.)

iii. Arup (Madrid \& lagos offices), Design Genre, Nigeria Energy Support Programme. (2016). Building Energy Efficiency Guideline for Nigeria. Abuja: Federal Ministry of Power, Works and Housing (Housing).

iv. Barshilia, K. (2014, May). Innovation in Design: A Study of Green Buildings. International Journal of Scientific and Research Publications, 4(5), (pp1-5.)

v. Council, U. G. (2002). Green Building Rating System for New Construction \& Major Renovations (LEED-NC) Version 2.1. U.S Green Building Council.

vi. Fedkin, M. (2018). 7.2 Assessment Tools for Sustainable Buildings l EME 807: Technologies for Sustainability Systems.mhtml. Retrieved September 07, 2019, from John A. Dutton e-Education Institute: http://www.eeducation.psu.edu/eme807/node/551

vii. Gibberd, J. (2009, January 20). Building envelope. Green Building Handbook for South Africa, (pp. 1-6.)

viii. Givoni B, H. B. (1968). Effect of building materials on internal temperature. Haifa: building research station Technion.

ix. Habitat, C. o. (2014, July). Pearl River Tower, Guangzhou. In J. Gang, Pearl River Tower has a steadfast environmental approach and advances the idea od intergrated renewable energy in high rise buildiings (pp. 1-4).

x. Harputlugil, T. (08 June 2017.). Energy Efficient Building Design Development: International Symposium on Energy Efficiency in Buildings, (pp. 296-303). Ankara, TURKEY: https://www.researchgate.net/publication/317415027.

xi. $\quad$ Hasim Altan, M. H. (2017, November 15). Passive Design. (M. Noguchi, Ed.) Research gate, (pp210-236.)

xii. Hossein Omrany, A. M. (2015). Optimization of Building Energy Performance. British Journal of Applied Science \& Technology, (pp. 1-16.) 
xiii. McGee, C. (2017). Your Home: Australia's Guide to Environmentally Sustainable Homes. 5th Edition. Sydney, Australia: Can Print Communications, Canberra.

xiv. Minner, K. (2010, October 23). Retrieved 2019, from archdaily.com: https://www.archdaily.com/83307/8-housebig/>ISSN0719-8884

xV. O.oseni, M. (2016). Get rid of it: To what extent might improved reliability reduce self-generation in Nigeria. Energy Policy , (pp. 246-254.)

xvi. Sciences., N. i. (2016, August 26). WBDG - Whole Building Design Guide. Retrieved October 2019, from http://www.nibs.org/

xvii. Wood, H. (2019). American Institute of Architects. Retrieved 2019, from https://www.aiatopten.org > node 